\title{
MOLECULAR DOCKING AKTIVITAS ANTIKANKER DARI KUERSETIN TERHADAP KANKER PAYUDARA SECARA IN SILICO
}

\author{
M. B. O. Rastini ${ }^{1}$, N. K. M. Giantari ${ }^{2}$, K. D. Adnyani ${ }^{1}$, dan N. P. L. Laksmiani ${ }^{1}{ }^{*}$ \\ ${ }^{1}$ Department of Pharmacy, Faculty of Mathematics and Natural Sciences, Universitas Udayana, \\ Bukit Jimbaran, Badung, Bali, Indonesia \\ ${ }^{2}$ Central Laboratory of Universitas Udayana, Bukit Jimbaran, Badung, Bali, Indonesia \\ *e-mail: lindalaksmiani@gmail.com
}

\begin{abstract}
ABSTRAK
Kanker payudara dapat diinisiasi salah satunya oleh ekspresi berlebih dari protein HER-2 yang dapat menginduksi terjadinya dimerisasi dan autofosforilasi sehingga memicu terjadinya aktivasi Focal Adhesion Kinase (FAK) sehingga mengakibatkan migrasi dan metastasis pada sel kanker payudara. Kuersetin yang memiliki nama lain 3,5,7,3', '4'-pentahydroxyflavon dengan rumus molekul $\left(\mathrm{C}_{15} \mathrm{H}_{10} \mathrm{O}_{7}\right)$ adalah senyawa golongan flavonoid yang sangat banyak terdapat di alam. Tujuan penelitian ini adalah untuk mengetahui mekanisme penghambatan ekspresi berlebih dari protein HER-2 oleh senyawa kuersetin secara in silico dengan molecular docking. Molecular docking secara in silico dilakukan dengan beberapa tahapan seperti validasi metode, optimasi struktur senyawa kuersetin 3D, dan docking antara senyawa kuersetin teroptimasi dengan protein HER2 yang mengacu pada parameter energi ikatan dimana semakin rendah nilai energi ikatan maka semakin kuat dan stabil ikatan yang terjadi antara senyawa kuersetin dengan protein HER-2. Diperoleh hasil docking berupa energi ikatan senyawa kuersetin dengan protein HER-2 yaitu -8,24 kkal/mol, sedangkan energi ikatan native ligand dengan protein HER-2 adalah -10,45 kkal/mol. Energi ikatan tersebut menunjukkan bahwa senyawa kuersetin memiliki potensi sebagai antikanker payudara karena mampu memodulasi ekspresi berlebih dari protein HER-2.
\end{abstract}

Kata kunci : kuersetin, kanker payudara, HER-2, in silico

\begin{abstract}
Breast cancer can be initiated by either overexpression of HER-2 protein which can induce dimerization and autophosphorylation so that it triggers the activation of Focal Adhesion Kinase (FAK) resulting in migration and metastasis in breast cancer cells. Quercetin which has another name 3,5,7,3 ', 4'-pentahydroxyflavon with the molecular formula of $\left(\mathrm{C}_{15} \mathrm{H}_{10} \mathrm{O}_{7}\right)$ is a flavonoid compound which is very widely found in nature. The purpose of this study was to determine the mechanism of inhibition of overexpression of HER-2 proteins by quercetin compounds by in silico molecular docking. In silico molecular docking was carried out in several stages namely method validation, optimization of $3 \mathrm{D}$ quercetin compound structure, docking between quercetin compounds optimized with HER-2 protein based on bond energy parameters the lower the bond energy the stronger and the more stable the bond is. The results of docking expressed by the binding energy of quercetin compounds with HER-2 protein are $-8.24 \mathrm{kcal} / \mathrm{mol}$, while the energy of the native ligand bond with HER-2 protein is $-10.45 \mathrm{kcal}$ / mol. The bonding energy shows that quercetin compounds have the potential as breast anticancer because they can modulate the overexpression of HER-2 proteins.
\end{abstract}

Keywords: quercetin, breast cancer, HER-2, in silico

\section{PENDAHULUAN}

Berdasarkan data Globocan, International Agency for Research on Cancer (IARC) tahun 2012, kanker payudara adalah kanker dengan persentase kasus tertinggi yaitu sebesar 43,3\% pada perempuan di dunia. Menurut Data Riset Kesehatan Dasar tahun 2013, prevalensi kanker payudara di Indonesia mencapai 0,5 per 1000 perempuan (Kemenkes RI, 2015).

Kanker payudara adalah tumor ganas yang dapat menyerang jaringan payudara yang terdiri dari kelenjar susu (kelenjar pembuat air susu), saluran kelenjar (saluran air susu), dan jaringan penunjang payudara. Kanker payudara menyebabkan sel dan jaringan payudara berubah bentuk menjadi abnormal dan bertambah banyak secara tidak terkendali (American Cancer Society, 2017). Pertumbuhan sel kanker yang tidak terkendali disebabkan kerusakan deoxyribose nucleic acid (DNA), sehingga menyebabkan mutasi gen vital yang mengontrol pembelahan sel. 
HER-2 (human epidermal growth factor receptor 2) berperan dalam proliferasi, migrasi, bertahan hidup dan pertumbuhan sel. Secara khusus 20-30 \% ekspresi berlebih dari HER-2 dapat menyebabkan perkembangan sel kanker payudara (Franklin et al., 2014). Ekspresi berlebih reseptor HER-2 akan mengaktivasi Bcl-2, Bcl-2 di dalam tubuh bersifat antiapoptosis sehingga akan mengalami proliferasi sel (Franklin et al., 2014). Ekspresi berlebih dari HER-2 juga dapat menekan apoptosis melalui mekanisme yang dapat mengganggu kedua jalur apoptosis yaitu jalur intrinsik dan ekstrinsik.

Pengobatan menggunakan antiestrogen tamoksifen merupakan terapi lini pertama untuk sebagian besar pasien dengan kanker payudara (Lykkesfeldt et al, 1994). Namun dalam tiga dasawarsa terakhir, ribuan wanita yang mendapat pengobatan tamoksifen mengalami penurunan respon atau bahkan tidak memberikan respon terhadap pengobatan kemoterapi kanker payudara. Hal tersebut mungkin terjadi karena timbulnya resistensi. Sekitar $40 \%$ pasien akhirnya kambuh dan meninggal karena resistensi setelah terapi selama 7-10 bulan (Ring et al, 2004; Wind et al, 2011).

Diperlukan suatu pengembangan terapi terhadap kanker payudara yang memiliki target spesifikdan selektifitas yang tinggi terhadap terapi kanker payudara dengan eksplorasi potensi bahan alam berkhasiat. Kuersetin ialah suatu senyawa golongan flavonoid yang sangat banyak terdapat di alam (Wach et al., 2007). Beberapa penelitian telah membuktikan bahwa senyawa kuersetin dapat menghalangi penyebaran berbagai jenis kanker seperti kanker paru-paru, prostat, hati, payudara, usus besar, dan leher rahim yang dapat beraksi sebagai antikanker pada regulasi siklus sel, yang berinteraksi dengan reseptor estrogen (ER) tipe II dengan menghambat enzim tirosin kinase ( Liu et al., 2017).

Menurut penelitian yang dilakukan Seo et al, 2016 kuersetin memiliki kemampuan untuk menghambat ekspresi berlebih reseptor HER-2. Dimana pada penelitian tersebut dilakukan uji in vivo yang menghasilkan nilai $\mathrm{IC}_{50}$ sebesar $120 \mu \mathrm{M}$. Pengujian terhadap potensi kuersetin sebagai agen antikanker payudara dapat dilakukan dengan mengetahui afinitas dan mekanisme molekuler dari kuersetin terhadap protein target HER-2 dengan menggunakan metode molecular docking secara in silico (pemodelan komputer). Teknik kimia komputasi ini dapat digunakan untuk mempercepat pemilihan senyawa yang akan diisolasi dan disintesis dengan mengidentifikasi dan optimasi senyawa penuntun dalam proses penemuan obat. Oleh karena itu, potensi kuersetin dalam menghambat ekspresi berlebih dari reseptor HER-2 dapat diketahui.

\section{BAHAN DAN METODE}

\section{Bahan}

Struktur 3 dimensi senyawa kuersetin diunduh pada website https://pubchem.ncbi.nlm.nih.gov/. Struktur protein target HER-2 (PDB ID: 3PP0) diunduh pada website PDB (protein data bank) yaitu http://www.rcsb.org/pdb/home/home.do.

Alat

Seperangkat komputer dengan spesifikasi Windows 864 bit yang dilengkapi program Hyperchem 8, Chimera 1.10.1 dan aplikasi AutoDock Tools dilengkapi program Autodock 4.2 dan Autogrid.

\section{Metode Penelitian}

\section{Optimasi Struktur 3 Dimensi Senyawa Kuersetin}

Struktur 3 dimensi senyawa kuersetin dioptimasi dengan menggunakan program Hyperchem 8. Optimasi dilakukan dengan metode komputasi semi-empiris AM1 (Austin Model 1) dan dilakukan kalkulasi single point dan optimasi geometri.

\section{Preparasi Struktur 3 Dimensi Protein HER-} 2

Preparasi protein dilakukan menggunakan program Chimera 1.10.1 dengan memisahkan struktur 3 dimensi protein HER-2 dengan native ligand-nya.

\section{Validasi Metode Molecular Docking}

Validasi metode molecular docking dilakukan menggunakan aplikasi Autodock Tools (Autodock 4.2 dan Autogrid) dengan men-docking-kan kembali (redocking) native ligand pada protein HER-2 yang sudah dihilangkan native ligand-nya. Parameter validasi metode adalah Root Mean Square Deviation (RMSD). RMSD yang dapat diterima adalah $\leq 3,0 \AA$ (Jain dan Nicholls, 2008). 


\section{Docking Kuersetin pada Protein HER-2}

Senyawa kuersetin yang telah dioptimasi di-docking-kan pada protein HER-2 yang sudah dihilangkan native ligand-nya menggunakan aplikasi Autodock Tools dengan prosedur docking yang sama seperti saat validasi metode. Hasil analisis menunjukkan konformasi ikatan senyawa pada protein dengan nilai energi ikatan dan ikatan hidrogen.

\section{Analisa Data}

Hasil molecular docking adalah energi ikatan dan ikatan hidrogen yang terbentuk. Energi ikatan digunakan untuk menunjukkan kekuatan ikatan antara senyawa dengan protein. Semakin rendah nilai energi ikatan, maka ikatan yang tersebntuk semakin kuat dan stabil. Jenis ikatan hidrogen yang terbentuk digunakan untuk menganalisis mekanisme interaksi yang terbentuk.

\section{HASIL DAN PEMBAHASAN}

\section{Optimasi Struktur 3 Dimensi Senyawa Kuersetin}

Struktur 3 dimensi senyawa kuersetin yang telah diunduh dilakukan optimasi dengan program Hyperchem 8 dengan metode komputasi semi empiris AM1 dengan tahapan optimasi yaitu kalkulasi single point dan optimasi geometri untuk mendapatkan struktur senyawa kuersetin yang paling stabil. Keberhasilan optimasi senyawa ditandai dengan energi total hasil optimasi geometri lebih kecil dibandingkan energi total hasil kalkulasi single point. Hasil optimasi senyawa kuersetin ditunjukkan pada gambar 1.

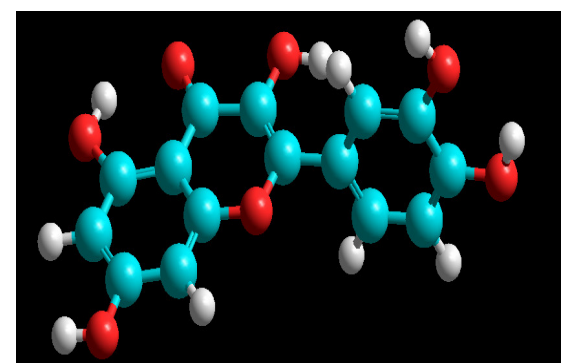

Gambar 1. Hasil Optimasi Struktur 3 Dimensi Senyawa Kuersetin.

Besar energi total hasil kalkulasi single point dan optimasi geometri yang diperoleh dari senyawa kuersetin berturut-turut yaitu $3699,525377 \mathrm{kkal} / \mathrm{mol}$ dan $-3711,7587$ $\mathrm{kkal} / \mathrm{mol}$. Pada proses optimasi geometri, energi total molekul diminimalisasi sehingga didapatkan struktur senyawa yang paling stabil (Fitriasari dkk., 2008). Berdasarkan hasil tersebut, diperoleh struktur kuersetin yang telah teroptimasi.

\section{Preparasi Protein HER-2}

Protein HER-2 dipreparasi dengan memisahkan protein dengan native ligand-nya menggunakan program Chimera 1.10.1 sehingga diperoleh struktur protein tanpa native ligand dan struktur native ligand yang terpisah seperti gambar 2. Pemisahan protein dengan native ligand bertujuan untuk menyediakan pocket sebagai tempat senyawa uji berikatan dengan protein HER-2. Rantai protein yang dipilih dalam pengujian ini adalah rantai A yang berikatan dengan native ligand 03Q (2 - \{2-[ 4 - ( \{ 5 - chloro - 6 - [ 3 - ( trifluoromethyl) phenoxy ] pyridine $-3-y$ l $\}$ amino )- $5 \mathrm{H}$ - pyrrolo [3,2 d ] pyrimidin-5-yl] ethoxy \} ethanol), yang berfungsi sebagai inhibitor HER-2 (Carpenter and Lo, 2013).

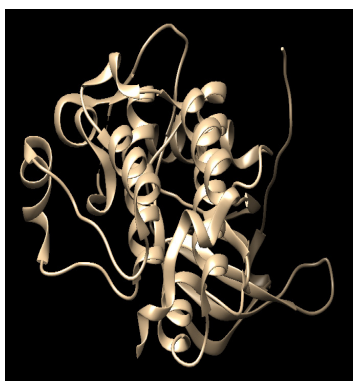

(a)

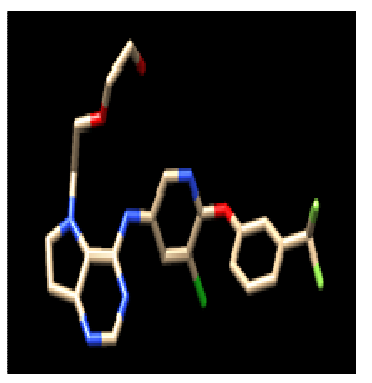

(b)
Gambar 2. Struktur 3 Dimensi Protein HER2 tanpa ligan (a) dan native ligand protein HER-2 (b)

\section{Validasi Metode Molecular Docking}

Validasi metode molecular docking dilakukan menggunakan aplikasi Autodock Tools dengan menambatkan ulang (redocking) native ligand protein HER-2 dengan protein HER-2 yang sudah dipreparasi. Parameter validasi metode adalah nilai RMSD. RMSD merupakan jarak penyimpangan dari posisi ikatan native ligand dengan protein setelah didocking-kan terhadap posisi ikatan native ligand yang sebenarnya (Nauli, 2014). Nilai RMSD ini dapat disebut pula dengan jarak ikatan. Nilai RMSD yang diperoleh pada penelitian ini adalah $0,7 \AA$ yang berarti bahwa metode molecular docking yang digunakan telah tervalidasi. Visualisasi interaksi validasi metode molecular docking dapat dilihat pada Gambar 3. 


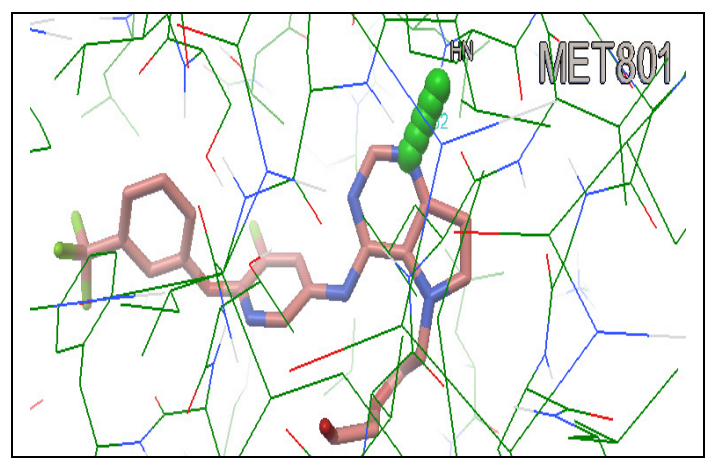

Gambar 3. Visualisasi interaksi protein HER2 dengan native ligand-nya.

\section{Docking Kuersetin pada Protein HER-2}

Docking senyawa kuersetin yang telah dioptimasi pada protein HER-2 dilakukan menggunakan aplikasi Autodock Tools dengan prosedur dan koordinat yang sama seperti pada validasi metode yang telah tervalidasi. Hasil docking kuersetin pada protein HER-2, diperoleh 10 konformasi ikatan antara kuersetin dengan protein HER-2, yang selanjutnya dipilih satu konformasi dengan nilai energi ikatan terendah yang menunjukkan ikatan paling stabil. Hasil docking antara kuersetin dan native ligand dengan protein HER-2 menunjukkan bahwa energi ikatan antara kuersetin dengan protein HER-2 bernilai negatif. Pada protein HER-2, kuersetin memiliki energi ikatan yang lebih tinggi dibandingkan dengan native ligand. Hal tersebut menunjukkan potensi kuersetin dalam berikatan dengan sisi aktif HER-2 lebih lemah dari native ligand-nya, tetapi tetap memiliki kemampuan untuk berikatan. Nilai energi ikatan native ligand dan kuersetin pada protein target HER-2 berturut-turut yaitu -10,45 kkal dan $-8,24 \mathrm{kkal} / \mathrm{mol}$ seperti yang ditunjukkan pada tabel 1. Berdasarkan hal tersebut senyawa kuersetin mampu berinteraksi dengan protein HER-2 dengan membentuk ikatan hidrogen pada asam amino MET801 yang mana ikatan hidrogen yang terbentuk tersebut sama dengan ikatan hidrogen yang terbentuk pada docking antara native ligand dengan protein HER-2. Hal ini menunjukkan sisi aktif tempat berikatan antara native ligand dan kuersetin pada protein HER-2 sudah sama sehingga akan menghasilkan afinitas yang sama pula dengan native ligandnya dalam menghambat protein HER-2. Visualisasi docking kuersetin dengan protein HER-2 ditunjukkan pada gambar 4.
Berdasarkan hasil yang diperoleh kuersetin menunjukkan aktivitas sebagai agen antikanker payudara dengan mekanisme penghambatan HER-2 melalui pembentukan ikatan hidrogen dengan afinitas yang ditunjukkan oleh energi ikatan yang bernilai negatif. Hal ini didukung oleh penelitian yang dilakukan oleh Seo et al, 2016 yang menyatakan bahwa kuersetin memiliki kemampuan untuk menghambat ekspresi berlebih reseptor HER-2. Dimana pada penelitian tersebut dilakukan uji in vivo yang menghasilkan nilai $\mathrm{IC}_{50}$ sebesar $120 \mu \mathrm{M}$.

Tabel 1. Hasil Docking Kuersetin dan Native ligand pada Protein HER-2

\begin{tabular}{llll}
\hline $\begin{array}{l}\text { Protein } \\
\text { Target }\end{array}$ & Ligan & $\begin{array}{l}\text { Energi } \\
\text { Ikatan } \\
(\mathrm{kkal} / \mathrm{mol})\end{array}$ & $\begin{array}{l}\text { Ikatan } \\
\text { Hidrogen }\end{array}$ \\
\hline HER-2 & $\begin{array}{l}\text { Native } \\
\text { ligand }\end{array}$ & $-10,45$ & MET801 \\
\hline & Kuersetin & 8,24 & MET801
\end{tabular}

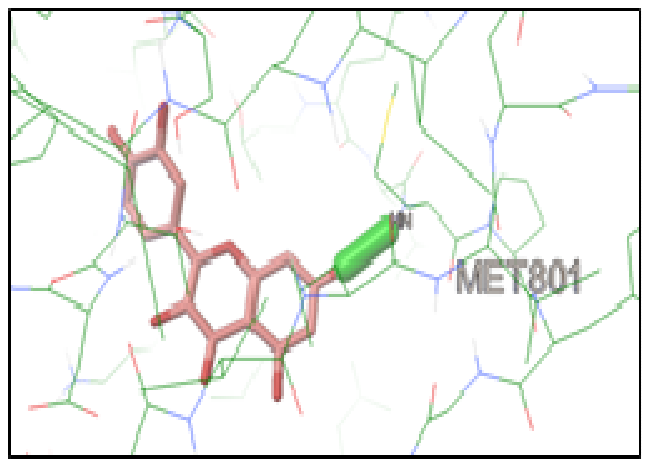

Gambar 4. Visualisasi Interaksi Hasil Docking Kuersetin pada Protein HER-2

\section{KESIMPULAN}

Kuersetin memiliki afinitas terhadap protein HER-2 dengan energi ikatan -8,24 $\mathrm{kkal} / \mathrm{mol}$. Kuersetin memiliki mekanisme molekular dalam menghambat HER-2 pada kanker payudara yang ditunjukkan melalui pembentukan ikatan hidrogen pada protein HER-2.

\section{UCAPAN TERIMA KASIH}

Penulis mengucapkan terima kasih kepada dosen pembiming, keluarga, temanteman, dan semua pihak yang telah membantu dan mendukung dalam penelitian ini. 


\section{DAFTAR PUSTAKA}

American Cancer Society. 2017. Breast Cancer Treatment Guideline. Atlanta: American Cancer Society.

Carpenter, R. L. dan Lo, H. 2013. Regulation of Apoptosis by HER2 in Breast Cancer. J Carcinog Mutagen, 7: 1-6.

Fitriasari, A., Wijayanti, N. K., Ismiyati, N., Dewi, D., Kundarto, W., A. Sudarmanto, B. S. dan Meiyanto, E. 2008. Studi Potensi Kurkumin dan Analognya sebagai Selective Estrogen Receptor Modulator (SERMs): Docking pada Reseptor Estrogen B. Pharmacon, 9(1).

Franklin, M. C., Carey, K. D., Vajdos, F.F., Leahy, D. J., Mdevos, A. M., dan Sliwskowski, M. X. 2004. Insight into ErbB signaling from the structure of the ErbB2-pertuzumab complex. Cancer Cell, 5: 317 -28.

Jain, A. J. dan Nicholls. A., 2008. Recommendations for evaluational methods. J. Comput. Aided Mol., 22: 133-139.

Kementerian kesehatan RI. 2015. Pusat Data dan Informasi (Stop Kanker). Kementrian Republik Indonesia. Jakarta Selatan.
Lykkesfeldt, A. E., Madsen, M. W., dan Briand, P. 1994. Altered Expression of Estrogen Regulated Genes in a Tamoxifen Resistant and ICI 164,384 and ICI 182,780 Sensitive Human Breast Cancer Cell Line, MCF7/TAMR-1. Cancer Research, 54: 15871595.

Nauli, T. 2014. Penentuan Sisi Aktif Selulase Aspergillus Niger dengan Docking Ligan. JKTI, 16(2).

Ring, A., Dowset, M. 2004. Mechanism of Tamoxifen Resistance. EndocrineRelated Cancer, 11: 643-648.

Seo et al, 2016, Quercetin Induces CaspaseDependdent Extrinsic Apoptosis Through Inhibition of Signal Transducer and Activator of Transcription 3 Signaling in HER 2-Overexpressing BT474 Breast Cancer Cells. Oncology Report, 36: 31-42.

Wach, A., Pyrzyn'ska, K., dan Biesaga, M., 2007, Quercetin Content in Some Food and Herbal Samples. Food Chemistry, 100: 699-704.

Wind, N. S., dan Holen, I. 2011. Multidrug Resistance in Breast Cancer: From In Vitro Models to Clinical Studies. International Journal of Breast Cancer, $1-10$. 